\title{
Penerapan Langkah Polya Untuk Meningkatkan Hasil Belajar Matematika Siswa Kelas 5 SDN Percobaan 2 Malang
}

\author{
Timbul Yuwono \\ Pendidikan Matematika, Universitas Kanjuruhan Malang \\ timbulyuwono@unikama.ac.id
}

\begin{abstract}
Abstrak
Penelitian ini di latar belakangi dari kesulitan siswa dalam menyelesaikan masalah hitung pecahan yang dikemas dalam soal cerita. Peneliti menggunakan salah satu alternatif pemecahan masalah melalui langkah-langkah Polya. Pembelajaran penyelesaian masalah dengan menggunakan langkah-langkah Polya ini dapat meningkatkan hasil belajar matematika siswa. Tujuan penelitian ini, yaitu untuk mendeskripsikan pelaksanaan pembelajaran dengan menerapkan langkah-langkah Polya dan Meningkatkan hasil belajar matematika siswa dengan menggunakan langkah Polya. Penelitian Tindakan Kelas (PTK) menggunakan model yang dikembangkan oleh Kemmis dan MC Taggart terjadi 3 siklus. Peneliti melakukan penelitian di siswa Sekolah Dasar kelas 5 SDN Percobaan 2 Malang. Hasil Pemecahan masalah siswa SDN Percobaan II Malang pada siklus 1 mencapai nilai rata-rata kelas 71,23. Pada siklus II mencapai nilai rata-rata kelas 83,4 sedangkan pada siklus III dengan nilai rata-rata kelas 84,27 . Berdasarkan hasil penelitian ini, dapat disimpulkan bahwa penerapan langkah-langkah polya dapat meningkatkan hasil belajar matematika siswa di SDN Percobaan 2 Malang.
\end{abstract}

Kata Kunci: Langkah Polya, Hasil Belajar, Soal Cerita

\begin{abstract}
This research is based on the difficulty of students in solving the problem of calculating fractions that are packaged in story problems. The researcher uses one alternative problem solving through Polya steps. Problem solving learning by using Polya steps can improve student mathematics learning outcomes. The purpose of this study, which is to describe: The implementation of learning by applying Polya steps and Improving student mathematics learning outcomes by using Polya steps. Classroom Action Research (CAR) using a model developed by Kemmis and MC Taggart happened 3 cycles. Researchers conducted research in elementary school students grade 5 SDN Percobaan 2 Malang. Results of Problem solving of grade 5 SDN Percobaan 2 Malang in cycle 1 reached an average grade of 71.23. In cycle II it reached an average grade of 83.4 while in cycle III it had an average grade of 84.27. Based on
\end{abstract}


the results of this study, it can be concluded that the application of polya steps can improve student mathematics learning outcomes at SDN Percobaan 2 Malang.

\section{Keywords : Step Polya, Learning Outcomes, Story Problems}

\section{A. PENDAHULUAN}

Siswa dalam penyelesaian masalah hitung pecahan mengalami kesulitan yang yang dikemas dalam cerita. Siswa memahami bacaan soal sering mengalami dalam merepresentasikan teks bacaan menjadi suatu operasi matematika. Kesulitan siswa dalam menyelesaikan masalah matematika, karena siswa belum belajar cara menyelesaikan masalah matematika. Siswa dalam belajar hitung pecahan yang dikemas dalam soal cerita, hasil belajarnya kurang memuaskan. Peneliti mengamati hasil jawaban siswa. Siswa masih melakukan kesalahan dalam melakukan penjumlahan maupun pengurangan bilangan pecahan dengan penyebut yang tidak sama. Hal tersebut disebabkan siswa pada saat membaca soal pemecahan masalah belum dapat informasi yang bermakna. Informasi bermakana yang dimaksud dalam menulis informasi yang diketahui tidak dapat menjadikannya untuk menyusun rencana penyelesain masalah. Siswa belum dapat menyatakan masalah yang sudah dibaca dengan kalimatnya sendiri. Peneliti menyimpulkan siswa masih belum mempunyai strategi dalam menyelesaikan masalah diantara strategi membaca untuk menjadi langkah penyelesaian masalah. Strategi dalam memahami bacaan

\footnotetext{
${ }^{1}$ Annemie Desoete, "Multi-Method Assessment of Metacognitive Skills in Elementary School Children: How You Test Is What You Get," Metacognition and Learning 3, no. 3 (December 2008): 189-206, https://doi.org/10.1007/s11409-008-9026-0.
}

pemecahan masalah penting diajarkan pada siswa sekolah dasar dan sekolah menengah.

Strategi membaca dalam pemecahan masalah menurut Desoete dalam menyelesaikan masalah anak perlu membaca masalah untuk memahami, menggarisbawahi kata-kata penting, memilih informasi yang relevan, membaca tugasnya lagi untuk memahami lebih baik, membuat gambar, menempatkan informasi bersama-sama, menuliskan apa yang diminta, menuliskan apa yang sudah diketahui, merefleksikan, memperkirakan hasil yang mungkin dan menunjukkan perilaku lain ke arah prediksi. ${ }^{1}$ Menurut Walker dkk prestasi siswa pada matematika dipengaruhi oleh tingkat kemampuan membaca. ${ }^{2}$ Siswa yang berada pada tingkat kemampuan membaca rendah cenderung kurang dapat menjawab dengan benar. Menurut Gama Perefleksian merupakan aktivitas dimana seseorang menangkap kembali pengalamannya, memikirkannya kembal mempertimbangkannya dan mengevaluasinya kembali. ${ }^{3}$

Siswa memerlukan kehati-hatian dalam memahami bacaan soal pemecahan masalah untuk memastikan bahwa dia mengerti apa yang dibaca. Siswa juga

\footnotetext{
2 "Walker 2008.Docx," n.d.

${ }^{3}$ Claudia Amado Gama, "Integrating Metacognition Instruction in Interactive Learning Environments," n.d., 246.
} 
memerlukan waktu lebih lama dalam memahami teks soal yang sulit, karena siswa harus memperhatikan, memvisualisasikan informasi untuk membantu mengingat dan mengerti dengan apa yang dibaca. Hal ini sesuai dengan pendapat Harvey dan Goudvis bahwa kesadaran memahami bacaan merupakan suatu proses yang berkelanjutan dan terus berkembang sesuai dengan apa yang dipikirkan pembaca. ${ }^{4}$ Siswa dalam belajar membaca bacaan atau soal pemecahan masalah perlu membaca berulang-ulang untuk mendapatkan informasi yang benar dalam soal pemecahan masalah tersebut. Menurut Rudyanto Kemampuan memahami isi bacaan tidak hanya diperlukan saat siswa mengikuti pelajaran Bahasa Indonesia. Hampir semua pelajaran membutuhkan kemampuan memahami isi bacaan, termasuk matematika yang sebagian besar berkaitan dengan berhitung. ${ }^{5}$

Siswa biasanya menyadari adanya masalah atas apa yang dibaca, tetapi kurang strategi untuk memperbaiki kebingungannya, sehingga ia memerlukan strategi membaca pemecahan masalah. Siswa yang menggunakan strategi membaca misalnya, membaca perlahanlahan dan hati-hati untuk mengerti apa yang ia baca, membacanya kembali untuk meningkatkan pemahamannya ketika menemui teks yang sulit. Menurut Desoete ketika anak-anak menyadari bahwa tugas adalah sulit, maka mereka lebih memperhatikan tugas tersebut dan bekerja lebih pelan agar kesalahan yang dibuat

\footnotetext{
${ }^{4}$ Stephanie Harvey and Anne Goudvis, "Teaching Comprehension to Enhance Understanding," n.d., 15.

${ }^{5}$ Hendra Erik Rudyanto, "Pengaruh Kemampuan Membaca Pemahaman Terhadap Prestasi Belajar Matematika Pada Pokok Bahasan Soal Cerita Kelas
}

berkurang. Berdasarkan pendapat Desoete tersebut siswa perlu mengendalikan proses berpikirnya selama menyelesaikan masalah ketika mengalami kesulitan. Siswa perlu membaca soal lebih lambat (membaca sambil berpikir) dan mengulang membaca ketika menemukan kesulitan. ${ }^{6}$

Masalah adalah situasi atau hal yang membutuhkan perhatian dan perlu ditangani atau dipecahkan. Masalah matematika dapat didefinisikan sebagai word problem (masalah kata), cerita atau masalah verbal yang merupakan deskripsi dari situasi, dalam kalimat maupun bilangan, yang membutuhkan jawaban. Kemampuan pemecahan masalah matematika juga dipengaruhi kemampuan membaca dan memahami masalah matematika. Keterampilan membaca dan memahami masalah matematika memiliki keterkaitan yang sangat erat dengan prestasi matematika. Strategi-strategi pemecahan masalah juga diperlukan siswa SD karena siswa-siswa tersebut sering mengalami kesulitan dalam pemecahan masalah. Menurut Phonaphichat kesulitan pemecahan masalah pada siswa kelas 5 dan 6 SD diklasifikasikan sebagai berikut; 1) Siswa memiliki kesulitan dalam memahami kata kunci yang muncul pada masalah, sehingga tidak bisa menafsirkannya menjadi kalimat matematika. 2) Siswa tidak mampu mencari tahu apa yang harus diasumsikan dan informasi apa yang diperlukan untuk memecahkan masalah itu. 3) Setiap kali

IV," Ibriez : Jurnal Kependidikan Dasar Islam Berbasis Sains 2, no. 2 (December 29, 2017): 175-82, https://doi.org/10.21154/ibriez.v2i2.34.

${ }^{6}$ Anne Desoete, "Off-Line Metacognition in Children with Mathematics Learning Disabilities,” n.d., 160. 
siswa tidak memahami masalah, mereka cenderung untuk menebak jawaban tanpa proses berpikir, 4) Siswa tidak sabar dan tidak suka membaca masalah matematika. 5) Siswa tidak suka membaca masalah yang sangat panjang. ${ }^{7}$

Berbagai pendapat di atas bahwa pemecahan masalah merupakan hal sangat penting dalam mempelajari matematika. Guru penting memberikan pembelajaran memecahkan masalah pada siswa di kehidupan sehari. Selain itu, siswa dalam membaca soal cerita tidak melakukan berulang-ulang untuk mendapatkan informasi penting yang dapat digunakan dalam menyelesaikan jawaban soal cerita tersebut. Siswa yang kesulitan memahami soal pemecahan masalah yang dikemas dalam soal cerita. Siswa dalam mengelola dalam mendapatkan informasi yang bermakna masih melakukan kesalahan, sehingga siswa juga akan mengalami kesulitan dalam menyusun rencana penyelesaian soal cerita tersebut. Siswa masih melakukan kesalahan dalam melaksanakan operasi perhitungan. Kesalahan dalam melakukan operasi perhitungan bilangan tersebut diketahui ketika guru melihat siswa saat menyelesaikan soal. Siswa tidak pernah memeriksa kembali hasil perhitungannya. Hal sesuai dengan apa yang dikemukan oleh Faradita Guru tidak mengasah keterampilan berpikir siswa khususnya keterampilan berpikir pemecahan

\footnotetext{
${ }^{7}$ Prathana Phonapichat, Suwimon Wongwanich, and Siridej Sujiva, “An Analysis of Elementary School Students' Difficulties in Mathematical Problem Solving," Procedia - Social and Behavioral Sciences 116 (February 2014): 3169-74, https://doi.org/10.1016/j.sbspro.2014.01.728.
}

masalah, siswa tidak dibimbing untuk memecahkan permasalahan yang ada tetapi guru lebih cenderung memberikan permasalahan sekaligus penyelesaiannya ${ }^{8}$

Peneliti melakukan observasi di SDN 2 Percobaan Malang menemukan adanya kesulitan siswa dalam menyelesaikan masalah yang banyak dikemas dalam soal cerita yang terdapat bilangan pecahan. Peneliti melakukan pengamatan siswa kelas 5 di SDN Percobaan 2 Malang yang dapat menyelesaikan masalah yang berkaitan dengan bilangan pecahan yang dikemas pada soal cerita hanya siswa 2 siswa dapat menyelesaikan dengan benar. Siswa tersebut menurut guru kelas masuk kategori siswa terpandai di kelasnya. Peneliti perlu mengajarkan cara mengerjakan tes pemecahan masalah untuk membantu siswa yang lain dengan prinsip langkah Polya. Peneliti menggunakan langkah-langkah Polya dalam pemecahan masalah matematika yang melibatkan bilangan pecahan yang dikemas dalam soal cerita. Pada awal observasi Peneliti mengamati siswa kelas V SD Percobaan 2 Malang megalami kesulitan dalam dalam menyelesaikan soal cerita yang melibatkan Konversi satuan, konversi desimal ke pecahan, Menjumlahkan pecahan dengan penyebut yang tidak sama. Pada tes Pendahuluan masih terdapat siswa yang menjumlahkan secara langsung penyebut yang tidak sama. Seorang guru penting menjelaskan secara

\footnotetext{
${ }^{8}$ Meirza Nanda Faradita, "Penerapan Pembelajaran CLIS dengan Menggunakan Alat Peraga Sederhana Untuk Meningkatkan Keterampilan Berpikir Pemecahan Masalah” 3, no. 2 (2018): 10.
} 
visual mengapa menjumlahkan bilangan pecahan perlu menyamakan penyebutnya karena penyebut adalah pembagi bagi pembilangnya, agar bilangan yang ingin dijumlahkan atau dikurangi pada dua bilangan atau lebih memiliki hasil bagi yang sama, sehingga bisa ditambah atau dikurangi. Hal Juga sesuai dengan pendapat Fatmanik bahwa penyebut disamakan karena untuk untuk membagi bagian itu menjadi bagian yang sama agara dapat dikurangkan. ${ }^{9}$

Berdasar studi pustaka dan emperis sudah dilakukan bahwa masih banyak siswa yang mengalami kesulitan dalam menyelesaikan Pemecahan masalah matematika soal cerita khususnya yang melibatkan bilangan pecahan. Peneliti memandang perlu peneltian tindakan kelas menggunakan langkah-langkah Polya untuk Meningkatkan Hasil Belajar Siswa Kelas 5 di SDN Percobaan 2 Malang. Peneliti tertarik dengan tema ini, karena siswa mengerjakan soal matematika khususnya soal pemecahan masalah yang dikemas dalam bentuk soal cerita, siswa mengalami kesulitan untuk menemukan jawaban yang benar. Prinsip langkah Polya dalam pemecahan masalah yang biasa dikemas dalam soal cerita yang dilakukan peneliti agar Hasil Belajar Siswa Kelas 5 di SDN Percobaan 2 Malang dapat meningkat.

Siswa kelas 5 SDN percobaan 2 Malang mengalami kesulitan dalam menyelesaikan soal pemecahan masalah yang dalam soal tersebut operasi bilangan pecahan. Solusi permasalahan tersebut

\footnotetext{
9 "Diagnosa Kesulitan Mahasiswa PGMI IAIN Ponorogo Dalam Membelajarkan Bilangan Pecahan.Pdf," n.d.
}

dengan pembelajaran matematika dengan menerapkan prinsip langkah-langkah polya untuk meningkatkan hasil belajar siswa. Prinsip langkah Polya ini dipilih, karena pembelajaran dengan menggunakan prinsip langkah polya melatih siswa berfikir sistematis dalam menyelesaikan masalah khususnya soal pemecahan masalah yang dikemas dalam soal cerita.

Menurut Polya Prinsip (1) Pahami masalahnya (Understanding the problem), (2) Rencanakan suatu rencana (Devising a plan), (3) Melaksanakan rencana (Carrying the plan), (4) melihat kembali (Looking back). ${ }^{10}$ Menurut Polya dalam memahami masalah. Implemenatsi dari prinsip langkah polya sebagai berikut:

1. Memahami Masalah masalah (Understanding the problem).

Siswa mengelolah atau mendapatkan informasi (apa yang dikehui dan ditanyakan) pada Tes Pemecahan Masalah. Siswa dapat menyatakan masalah dengan kalimatnya sendiri.

2. Membuat Rencana (Devising a plan) Penyelesain Masalah

Siswa menghubungkan apa yang sudah diketahui dan apa yang belum diketahui. Bagaimana siswa membuat strategi untuk mencari apa yang belum diketahui dari apa yang sudah diketahui.

3. Melaksanakan rencana (Carrying the plan) yang dibuat.

10 “Polya_HowToSolveIt.Pdf," n.d. 
Siswa melaksanakan atau apa yang sudah direncanakan dengan menuliskan apa yang sudah diketahui dalam bentuk langkah-langkah atau prosedur penyelesaian masalah dan siswa juga melakukan perbaikan/koreksi pada saat kegiatan kognitif menuliskan penyelesain masalah.

4. Melihat kembali (Looking back) pekerjaanya

Siswa melihat/mengevaluasi kembali hasil pekerjaannya mencocokkan/mensubtitusi jawaban yang diperoleh dengan permasalahan yang ada. Siswa melihat jawaban langkah awal sampai akhir jawaban dan menyimpulkan jawaban yang diperoleh dari keyakinan apa yang sudah dipikirkannya.

Berdasarkan hal tersebut, peneliti perlu untuk melakukan penelitian tindakan kelas dengan dengan tema "Penerapan Langkah Polya Untuk Meningkatkan Hasil Belajar Matematika di SDN Percobaan 2 Malang." Penelitian ini bertujuan untuk mendeskripsikan

perencanaan, pelaksanaan pembelajaran dan menilai peningkatan hasil belajar matematika khusus soal pemecahan masalah yang dikemas dalam soal cerita di SDN Percobaan 2 Malang.

\section{B. METODE PENELITIAN}

Penelitian Tindakan Kelas (PTK) bertujuan perbaikan transfer pengetahuan dari guru ke siswa melalui tindakan guru ke siswa baik sebagian maupun keseluruhan siswa dikelas. Penelitian
Tindakan Kelas ini diharapkan tercapai proses belajar mengajar yang efektif dan efisien sehingga meningkatkan hasil belajar matematika siswa. sesuai dengan capain kompetensi yang ditetapkan. Tempat penelitian adalah di SDN Percobaan 2 Malang dengan subjek penelitian adalah siswa kelas $5 \mathrm{~B}$.

Penelitian Tindakan Kelas ini menurut Maxwell berdasarkan Kemmis dan McTaggart dilakukan dalam siklus reflektif tediri dari - Perencanaan (Planning), Bertindak (acting), Mengamati (Observing) dan Refleksi (Reflection). ${ }^{11}$ Seperti pada tampak pada Gambar 1. Peneliti melakukan kegiatan siklus sebagai berikut; (1). Perencanaan pada waktu ini Peneliti menyiapkan rencana pelajaran di setiap siklus, menyiapkan Tes Pemecahan Masalah dan menyiapkan lembar observasi yang diisi oleh guru sebagai observer ketika peneliti mengajar menganalisis dan mendiskusikan hasil pengamatan dan hasil Tes Pemecahan Masalah setiap siklus. (2). Menerapkan pada waktu ini peneliti mengajarkan materi dengan menggunakan prinsip langkah polya dalam menyelesaikan soal pemecahan masalah bilangan pecahan yang dikemas dalam soal cerita. (3). Mengamati pada waktu ini pengamatan dilakukan oleh observer dan peneliti selama proses belajar mengajar. Observer dan peneliti mengamati kegiatan siswa dan kemudian hasil pengamatan diisi dalam lembar observasi.(4). Merefleksikan pada waktu ini peneliti dan observer membahas tentang kelebihan dan kekuangan suatu

\footnotetext{
11 T W Maxwell, "Action Research for Bhutan?," n.d.,
} 15 . 
siklus untuk melengkapi kekurangan dan apa seharusnya dilakukan dalam siklus berikutnya dan untuk menentukan apakah hasil dari siklus memuaskan atau tidak. Desain Penelitian tindakan kelas tampak seperti Gambar 1

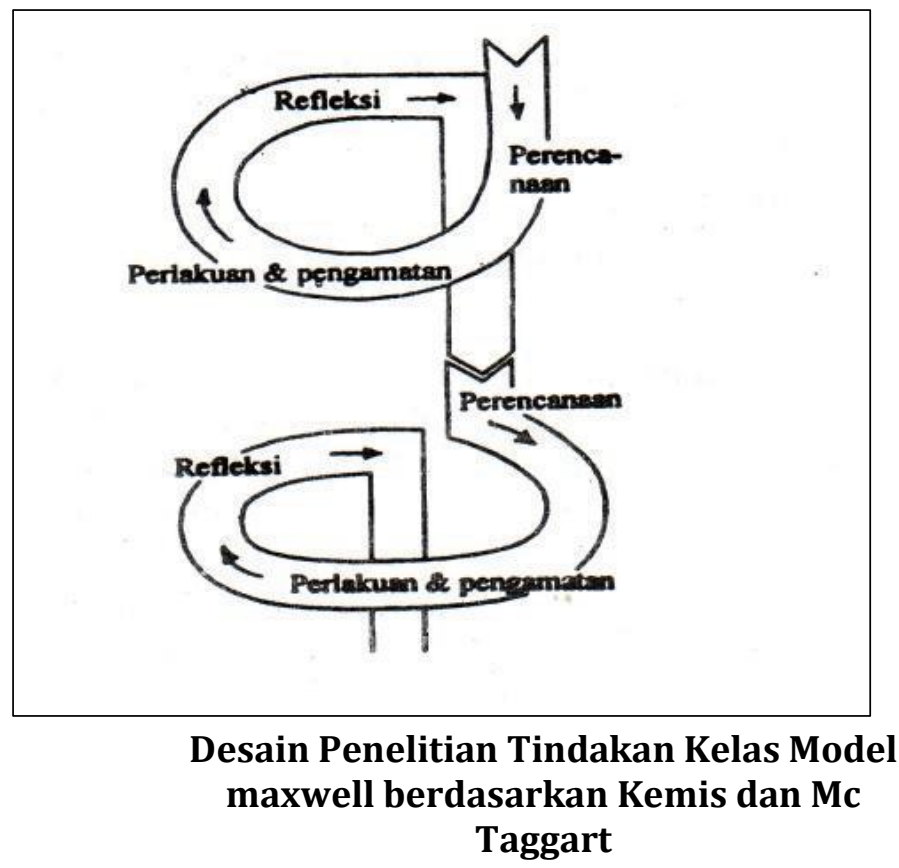

\section{HASIL DAN PEMBAHASAN}

Peneliti menyusun Rencana Pelaksanaan Pembelajaran (RPP) untuk beberapa pertemuan. Peneliti melakukan observasi pada kegiatan guru kelas 5 di SDN Percobaan 2 Malang dalam pembelajaran matematika di kelas sebelum melakukan penelitian. Peneliti mengamati guru kelas menggunakan pendekatan pembelajaran berpusat pada guru (center teacher learning), tetapi pendekatan pembelajaran ini kurang dapat mengekprorasi berfikirnnya siswa dalam menyelesaikan masalah.. Guru menggunakan metode ceramah, seharusnya diikuti dengan tanya jawab dengan siswa kemudian dilanjutkan dengan siswa mengerjakan soal-soal tes pemecahan masalah peneliti memberikan bantuan secukupnya dalam pembelajaran. Beberapa siswa dalam belajar materi LKS masih belum tertib, sehingga peneliti perlu mengingatkan untuk menjaga ketenangan di kelas. Penggunaan Buku Tema pada siswa yang pada pelajaran matematika tidak secara berurutan secara konseptual sehingga siswa sering mengalami kesulitan dalam soal-soal pemecahan masalah yang banyak dikemas dalam bentuk soal cerita.

Penelitian ini menggunakan aktivitas Lembar Kerja Siswa (LKS) yaitu menyelesaikan 4 soal Tes Pemecahan Masalah yang dikemas dalam soal cerita. Siswa diharuskan berdiskusi dan bekerjasama dalam kelompoknya. Peneliti melakukan pembelajaran di siklus 1 terdiri dari kegiatan awal menjelaskan langkahlangkah polya, kegiatan pelaksanakan langkah-langkah polya dalam menyelesaikan soal pemecahan masalah dan kegiatan akhir mengulas pekerjaan yang sudah dilaksankan. Peneliti melaksanakan penelitian tindakan kelas ini menerapkan prinsip langkah polya dalam menyelesaikan soal pemecahan masalah yang dikemas dalam soal cerita. Hasil pekerjaan siswa di analisis. Peneliti dan siswa dalam pembelajaran diamati oleh seorang observer. Hasil analisis RPP pada siklus I, Peneliti mendapatkan nilai akhir 3,68 sesuai dengan standart pembelajaran yang ditetapkan dengan kategori baik. Hasil aktivitas peneliti dalam pembelajaran mendapatkan nilai 3,41 dan juga sudah sesuai dengan standar yang ditetapkan dengan kategori baik. Aktivitas siswa dalam pembelajaran mendapatkan nilai 3,31 juga sudah sesuai dengan standart yang ditetapkan dengan kategori 
baik dan rata-rata nila siswa adalah 71,23 dengan 14 orang siswa memenuhi KKM yaitu 75 sesuai dengan yang ditetapkan sekolah dan 16 orang siswa belum lulus KKM.

Pada siklus II, RPP disusun setelah Peneliti melakukan refleksi terhadap pembelajaran yang telah dilakukan dan hasil belajar yang dicapai. Peneliti berdiskusi dengan guru sebagai observer untuk perbaikan yang akan dilakukan. Pada siklus II Peneliti menganalisis RPP dengan hasil 3,82 dengan kategori sangat baik. Peneliti menganalisis hasil aktivitas pembelajaran yaitu 3,78 dengan kategori sangat baik artinya pembelajaran sudah standart yang sudah di tetapkan. Peneliti menganalisis aktivitas pembelajaran siswa yaitu 3,58 dengan kategori baik artinya pembelajaran sudah sesuai dengan apa yang sudah ditetapkan. Peneliti melakukan rekapitulasi rata-rata nilai siswa 83,4 dengan 22 orang siswa memenuhi KKM dan 8 orang siswa belum lulus KKM.

Pada siklus III, RPP disusun setelah Peneliti melakukan refleksi pembelajaran yang sudah dilakukan dan hasil belajar yang telah dicapai oleh siswa. Peneliti berdiskusi dengan observer terkait perbaikan yang harus dilakukan. Peneliti melakukan pembelajaran pada siklus III dengan nilai analisis RPP yaitu 3,93 dengan kategori sangat baik. Hasil aktivitas peneliti dalam pembelajaran sudah sesuai dengan standart yang ditetapkan yaitu 3,75 dengan kategori sangat baik. Peneliti menganalisis hasil aktivitas siswa dalam pembelajaran juga sudah sesuai dengan standart yang ditetapkan yaitu 3,81 dengan kategori sangat baik. Hasil rekapitulasi rata-rata nilai siswa 84,87 dengan 25 siswa lulus KKM dan 5 siswa belum lulus KKM. Kelima siswa yang belum lulus KKM menjadi bahan refleksi untuk didiskusikan guru kelas matematika, tetapi mengalami peningkatan nilai pada Siklus III.

Peneliti dalam melaksanakan siklus I, II dan III melakukan perbaikan RPP yang disesuaikan dengan temuan di dalam kelas dan hasil diskusi antara peneliti dengan guru kelas (obsever). Peneliti dalam melaksanakan RPP mencapai peningkatan terlihat pada penilaian yang dilakukan oleh observer terhadap RPP yang digunakan Peneliti. Penilaian RPP yang digunakan peneliti pada siklus I dikategorikan baik mencapai 92 \%. Pada siklus II Penilaian RPP yang digunakan peneliti 95,5\%. Pada siklus III mendapatkan penilaian RPP yang digunakan peneliti 98,25 \% seperti tampak Pada Tabel 1. Pada siklus I sampai siklus III peneliti sudah menggunakan RPP sesuai dengan yang telah direncanakan. Hal ini juga dapat dikatakan penyusunan RPP dan prakteknya dilapangan sesuai.

Tabel 1. Rekapitulasi Penilaian

\begin{tabular}{lccc}
\hline $\begin{array}{l}\text { Jenis } \\
\text { Penilaian }\end{array}$ & $\begin{array}{c}\text { Siklus I } \\
\text { (\%) }\end{array}$ & $\begin{array}{c}\text { Siklus } \\
\text { II (\%) }\end{array}$ & $\begin{array}{c}\text { Siklus } \\
\text { III (\%) }\end{array}$ \\
\hline $\begin{array}{l}\text { Penilaian } \\
\text { RPP }\end{array}$ & 92 & 95,5 & 98,25 \\
$\begin{array}{l}\text { Aspek } \\
\text { Siswa }\end{array}$ & 85,5 & 89,5 & 95,5 \\
$\begin{array}{l}\text { Hasil } \\
\text { Belajar }\end{array}$ & 71,23 & 83,4 & 84,27 \\
\hline
\end{tabular}

Pada pelaksanaan pembelajaran dengan menggunakan prinsip langkah polya dari siklus I, II dan III mengalami peningkatan 
sesuai dengan rencana yang telah dibuat. Penilaian hasil belajar pada siklus I $(71,23)$ masih dalam kategori baik meningkat menjadi 84,27 kategori sangat baik pada siklus III. Peneliti melakukan refleksi pada setiap siklus 1 dan siklus II agar pembelajaran sesuai dengan standart yang ditetapkan. Peneliti berdiskusi dengan Guru kelas selaku observer untuk merumuskan perbaikan untuk siklus selanjutnya. Berdasarkan Tabel 1. Peneliti aktivitas pembaelajarannya pada siklus I mendapat capaian nilai yang baik yaitu 3,51 (87,75\%) dengan kategori baik. Pada siklus II meningkat menjadi 3,78 (94,5\%) dengan kategori sangat baik. Pada siklus III meningkat mencapai 3,85 (96,25\%) dengan kategori sangat baik. Dari data tersebut, jelas bahwa aktivitas peneliti dalam pembelajaran setiap siklusnya mengalami peningkatan. Hasil dari aktivitas peneliti pada siklus I sampai III baik dan sangat baik, artinya peneliti sudah melakukan pembelajaran yang sudah standart.

Prinsip Langka Polya Untuk Meningkatkan Hasil Belajar Matematika Siswa pada dengan menggunakan soal cerita mengalami peningkatan dari setiap siklusnya. Nilai rata-rata siswa pada siklus I sampai III terjadi peningkatan, pada siklus mendapatkan 71,23, siklus II mendapatkan 83,4 siklus III mendapatkan 84,27. Setelah melakukan penelitian kebanyakan siswa kesulitan memahami soal pemecahan masalah yang dikemas dalam soal cerita terutama dalam menentukan yang diketahui, ditanyakan menyatakan kembali dengan bahasanya sendiri apa yang menjadi solusi dari masalah tersebut. Siswa kesulitan dalam menerjemahkan soal cerita menjadi kalimat matematika. Siswa melakukan perbaikan kesalahan yang sudah dilakukan pada langkah memeriksa kembali, tetapi belum mengarah ke jawaban yang benar. Siswa dalam melihat kembali hasil pekerjaanya kurang cermat, sehingga banyak ditemukan kesalahan perhitungan. Kesulitan siswa dalam menyelesaikan soal cerita secara garis besar dapat dikelompokkan sebagai berikut:

a) Kesulitan siswa dalam menuliskan unsur-unsur yang diketahui dan tidak diketahui dalam masalah atau menuliskan informasi-informasi yang penting dalam masalah. Siswa belum dapat menyatakan kembali masalah tersebut secara lebih sederhana dalam bentuk notasi atau simbol atau gambar

b) Kesalahan siswa dalam menyusun rencana penyelesaian, yaitu siswa belum dapat menyusun informasi yang telah diketahui menjadi kalimat matematika.

c) Kesalahan siswa dalam menyelesaikan rencana, yaitu siswa melaksanakan rencana yang dilakukan, tetapi rencana yang sudah dibuat masih mengarah ke jawaban yang salah.

d) Kesalahan siswa dalam melihat kembali hasil yang telah diperoleh, yaitu siswa belum dapat mengecek hasil jawaban yang diperoleh dengan pertanyaan soal yang memungkinkan siswa dapat mengetahui (mendekeksi) bahwa jawaban benar atau salah. 


\section{PENUTUP}

\section{Simpulan}

Peneliti dalam menggunakan prinsip langkah polya dalam pembelajaran dapat menyusun dengan baik dan dapat memberikan hasil belajar matematika yang memuaskan. Pengamat menilai rencana pembelajaran selama penelitian ini dapat dilaksanakan sangat baik. Peneliti melaksanakan pembelajaran matematika dengan menerapkan prinsip langkah polya pada soal pemecahan masalah yang dikemas dalam soal cerita dapat meningkatkan hasil belajar matematika siswa. Siswa melaksanakan aktivitas pembelajaran berdasarkan hasil observasi pengamat dapat terlaksana dengan sangat baik. Hasil aktivitas peneliti dan siswa tersebut sudah sesuai dengan standart belajar yang sudah ditetapkan, sehingga penilain hasil belajar siswa dapat memenuhi standart penilaian

\section{Saran}

Saran untuk penelitian selanjutnya untuk membuat soal-soal masalah praktis di penjualan barang-barang yang berdiskon yang berbeda-beda. Sehingga siswa dapat cermat dalam mengambil keputusan yang tepat dalam membeli suatu barang yang berbeda-beda diskon,

\section{E. DAFTAR PUSTAKA}

Desoete, Anne. "Off-Line Metacognition in Children with Mathematics Learning Disabilities," n.d., 160. Desoete, Annemie. "Multi-Method Assessment of Metacognitive Skills in Elementary School Children: How You Test Is What You Get."
Metacognition and Learning 3, no. 3

(December 2008): 189-206. https://doi.org/10.1007/s11409008-9026-0.

Fatmanik, Ulum (2019)“Diagnosa Kesulitan Mahasiswa PGMI IAIN Ponorogo Dalam Membelajarkan Bilangan Pecahan.Pdf," n.d.

Faradita, Meirza Nanda. "Penerapan

Pembelajaran CLIS dengan Menggunakan Alat Peraga Sederhana Untuk Meningkatkan Keterampilan Berpikir Pemecahan Masalah" 3, no. 2 (2018): 10.

Gama, Claudia Amado. "Integrating

Metacognition Instruction in Interactive Learning Environments," n.d., 246. Harvey, Stephanie, and Anne Goudvis.

"Teaching Comprehension to Enhance Understanding," n.d., 15.

Maxwell, T W. "Action Research for Bhutan?," n.d., 15.

Phonapichat, Prathana, Suwimon

Wongwanich, and Siridej Sujiva.

"An Analysis of Elementary School Students' Difficulties in

Mathematical Problem Solving."

Procedia - Social and Behavioral

Sciences 116 (February 2014):

3169-74.

https://doi.org/10.1016/j.sbspro.2 014.01.728.

"Polya_HowToSolveIt.Pdf," n.d.

Rudyanto, Hendra Erik. "Pengaruh

Kemampuan Membaca Pemahaman Terhadap Prestasi Belajar Matematika Pada Pokok Bahasan Soal Cerita Kelas IV." Ibriez : Jurnal Kependidikan Dasar Islam Berbasis Sains 2, no. 2 (December 29, 2017): 175-82.

https://doi.org/10.21154/ibriez.v2 i2.34.

“Walker 2008.Docx," n.d. 